\title{
EFFECT OF SOMATOSTATIN ON LABELED 5-HYDROXYTRYPTAMINE RELEASE FROM RAT SPINAL CORD AND METHIONINE ENKEPHALIN ANTAGONISM IN VIVO
}

\author{
Huei-Yann TSAI*, Sadaaki MAEDA and Reizo INOKI \\ Department of Pharmacology, Osaka University Dental School, Osaka 530, Japan \\ *Department of Pnarmacology, China Medical College, Taichung 400. Taiwan
}

Accepted April 28, 1983

Brazeau et al. (1) first isolated the tetradecapeptide, somatostatin, from bovine hypothalmus as a potent inhibitory factor of putuitary hormone secretion. This substance has been found to be widely distributed in the central nervous system (2-4) and has also been considered as a neurotransmitter (5. 6). In addition to its neuroendocrine role, the stimulating effects of somatostatin on the release of acetylcholine from rat hippocampal synaptosomes (7), the release of norepinephrine from rat cerebral cortex (8). the turnover rate of DOPA, 5-hydroxytryptophan and 5-hydroxyindoleacetic acid in rat brain (9), and the secretion of histamine from rat mast cells (10) were reported. This study was carried out to determine the effect of somatostatin on 5-hydroxytryptamine (5$\mathrm{HT}$ ) release and the relationship in 5-HT release between somatostatin and methionine enkephalin (met-EK) in the spinal cord.

The effect of somatostatin on 5-HT release from the spinal cord was determined by spinal perfusion. Male Sprague Dawley rats, weighing between $200-250 \mathrm{~g}$, anesthetized with urethane $(1.2 \mathrm{~g} / \mathrm{kg}$, i.p.) were used. The rat's brain was fixed on a stereotaxic instrument. A stainless steel cannula as a pull-tube was inserted into the cisterna magna, and a polyethylene tube (no. 10) as a push-tube was also inserted intrathecally from the iumbosacral enlargement. Oxygenated Krebs-bicarbonate solution (composition in $\mathrm{mM}: \mathrm{NaCl}, 120 ; \mathrm{KCl}, 5 ; \mathrm{NaHCO}_{3}$.
15: $\mathrm{CaCl}_{2}, 1.5: \mathrm{MgSO}_{4}, 1.0$; glucose, 10), which contained $7.5 \times 10^{-5} \mathrm{M}$ pargyline to prevent the metabolism of $5-\mathrm{HT}$, was used as a perfusate. The spinal cord was first perfusated circularly with the Krebs-bicarbonate solution containing ${ }^{3} \mathrm{H}-5-\mathrm{HT}$ (1 $\mu \mathrm{Ci}$, specific activity: $32.1 \mathrm{Ci} / \mathrm{mmol}$ ) for $40 \mathrm{~min}$ at $37^{\circ} \mathrm{C}$. After the incubation, the spinal cord was continuously perfused for $20 \mathrm{~min}$ with Krebsbicarbonate solution containing $7.5 \times 10^{-5} \mathrm{M}$ pargyline and $3.75 \times 10^{-5} \mathrm{M}$ desipramine. Then, the perfusated samples were collected at every $5 \mathrm{~min}$ interval $(0.25 \mathrm{ml} / \mathrm{min})$ to the end of the experiment through the pull-tube.

Neuropeptides (somatostatin: 10 and 30 $(\mathrm{M}$. met-EK: $40, \alpha \mathrm{M}$ ) were added into the perfusate medium, and their effects on the release of ${ }^{3} \mathrm{H}-5-\mathrm{HT}$ were observed. The radioactivity in each fraction was measured in a liquid scintillation spectrometer (Aloka. LSC-673) and the release of 5 -HT was expressed as $d p m \times 10^{2} /$ tube. Statistical analysis of the difference was carried out in a pair experiment using Student's $t$-test. It was checked in another experiment using a Sephadex G-10 column that approx. $40 \%$ of the total radioactivities measured in the perfusate was due to 5-HIAA, a metabolite of 5-HT and others. The 5-HT release evoked by $20 \mathrm{mM} \mathrm{KCl}$ was also examined. The 5-HT release from the spinal cord was dose-dependently incresed by somatostatin (Fig. 1). This effect of somatostatin (30 $\mu \mathrm{M})$ was significantly antagonized 
by $40 \mu \mathrm{M}$ met-EK, which alone showed no considerable change in 5-HT release (Fig. 2).

Enkephalin-containing interneurones are rich in the substantia gelatinosa on the spinal

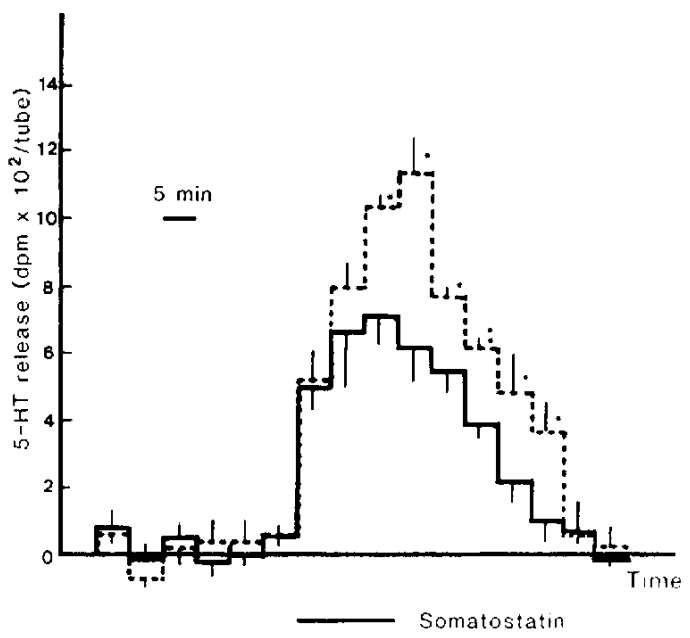

Fig. 1. Effect of somatostatin on 5.HT release in rat spinal cord. Each result shows the mean \pm S.E.M. of 4 experiments. Solid line represents $10 \mu \mathrm{M}$ somatostatin, and the broken line represents $30 \mu \mathrm{M}$. ${ }^{*} P<0.05, * * 0<0.01$

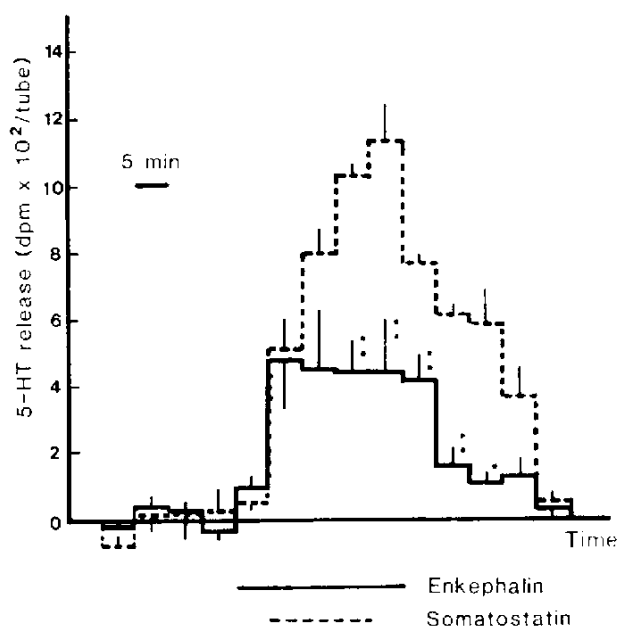

Fig. 2. Antagonism of met-enkephalin on 5-HT release evoked by $30 \mu \mathrm{M}$ somatostatin in rat spinal cord. Each result shows the meantS.E.M. of 4 experiments. The broken line shows $30 \mu \mathrm{M}$ somatostatin only, and the solid line shows $30, \mu \mathrm{M}$ somatostatin plus $40 \mu \mathrm{M}$ met-enkephalin. ${ }^{*} \mathrm{P}<0.05$. $*$ * $<0.01$. cord, suggesting that EK has a physiological role in the transmission of nociceptive information in the central nervous system (11). Somatostatin located in small neuronal cell bodies in the spinal ganglia and somatostatin-positive fibers were also found in the spinal dorsal horn, Lissauer's fasciculus and adjacent area of the lateral funiculus $(12,13)$. Somatostatin was considered as a neuromodulator. which was examined on both pre and postsynaptic sites in frog spinal cord (14). The physiological role of somatostatin in the spinal cord is not clearly known. Recently, however, some reports have shown that it may have a role as an inhibitory transitter substance in the spinal sensory pathways (15).

Many studies have shown that one of the most important descending pain modulatory pathways is a serotonergic system which originates from nucleus raphe magnus to the spinal dorsolateral funiculus (16-18).

In this study, we found that 5-HT release from the spinal cord was evoked by somatostatin. but not by met-EK: and moreover. the effect of somatostatin on 5-HT release was antagonized by met-EK. As we already found in an in vitro experiment (19) that 5 - HT release from rat spinal slices was evoked by somatostatin, and it was not suppressed by met-EK at all, it may suggest with the present finding that met-EK seems to act on sites further up from the spinal cord.

\section{References}

1) Brazeau, P., Vale, W., Burgus, R., Ling, N., Butcher, M., Rivier, J. and Gillemin, R.: Hypothalamic polypeptide that inhibits the secretion of immunoreactive pituitary growth hormone. Science 179,77-79 (1973)

2) Patel, Y.C. and Reichlin, S.: Somatostatin in hypothalamus, extrahypothalamic brain. and peripheral tissue of the rat. Endocrinology 102 , 523-530 (1978)

3) Epelbaum, J., Brazeau, P., Tsang, D., Brawer, J. and Martin, J.J.: Subcellular distribution of radioimmunoassayable somatostatin in rat brain. Brain Res. 126, 309-323 (1977) 
4) Emson, P.C., Rossor, M. and Lee, C.M.: The regional distribution and chromatographic behavior of somatostatin in human brain. Neurosci. Lett. 22, 319-324 (1981)

5) Bennett-Clark, C., Romagnano, M.A. and Joseph, S.A.: Distribution of somatostatin in the brain: Telencephalon and dienceohalon. Brain Res. 188, 473-486 (1980)

6) Hökfelt, T., Elfrin, L.G., Elde, R., Schulzberg, M., Goldstein, M. and Luft, R.: Occurrence of somatostatin-like immunoreactivity in some peripheral sympathetic noradrenergic neurons. Proc. Natl. Acad. Sci. U.S.A. 74, 3587-3591 (1977)

7) Nemeth, E.F. and Copper, J.R.: Effect of sumatostatin on acetylcholine release from rat hippocampal synaptosomes. Brain Res. 165 , 166-170(1979)

8) Tsujimoto, A. and Tanaka, S.: Stimulation effect of somatostatin on norepinephrine release from rat brain cortex slices. Life Sci. 28, 903-910 (1981)

9) Garcia-Sevilla, J.A., Mugnasson, T. and Darlsson, A.: Effect of intracerebroventricularly administered somatostatin on brain monoamine turnover. Brain Res. 155, 159-164 (1978)

10) Theoharides, T.C., Betchaku, T. and Douglas, W.W.: Somatostatin induced histamine secretion in mast cells: Characterization of the effect. Eur. J. Pharmacol. 69, 127-137 (1981)

11) Snyder, S.H., Uhl, G.R. and Kuhar, M.J.: Comparative features of enkephalin and neurotensin in the mammalian central nervous system. In Centrally Acting Peptides, Edited by
Hughes, J., p. 85-98. The MacMillan Press Ltd.. London and Basingstoke (1978)

12) Hökfelt, T., Elde, R., Johansson, O., Luft, R., Nilsson, G. and Arimura, A.: Immunohistochemical evidence for the presence of somatostatin, a powerful inhibitory peptide in some primary sensory neurones. Neurosci. Lett.. 1, 231-235 (1975)

13) Hökfelt, T., Elde, R., Johansson, O., Luft, R., Nilsson, G. and Arimura, A.: Immunohistochemical evidence for separate population of somatostatin-containing and substance $P$ containing primary afferent neurons in the rat. Neuroscience 1, 131-136(1976)

14) Padjen, A.L.: Effects of somatostatin on frog spinal cord. Neurosci. 3, Abs. 411 (1977)

15) Elde, R. and Hökfelt, T.: Localization of hypophysiotropic peptides and other biologically active peptides within the brain. Annu. Rev. Physiol. 41, 587-602 (1979)

16) Basbaum, A.I. and Fields, H.L.: Endogenous pain control mechanism: Review and hypothesis. Ann. Neurol. 4, 451-462 (1978)

17) Basbaum, A.I. and Ralston, H.J.: Projections from the nucleus raphe magnus in the primate. Pain 1, Abs. 259 (1978)

18) Fields, H.L., Basbaum, A.I., Clanton, C.H. and Anderson, S.D.: Nucleus raphe magnus inhibition of spinal cord dorsal horn neurons. Brain Res. 126, 441-453 (1977)

19) Maeda, S., Tsai, H.-Y., Iwatsubo, K. and Inoki, R.: Effects of neuroactive peptides on $5-H T$ release from spinal slices of rat. Folia Pharmacol. Japon. 79, 5P (1982) (in Japanese) 